\title{
SSynthesis
}

International Scientific Conference of IT and Business-Related Research

\section{EFEKTIVNOST METODA REGRUTOVANJA U PROCESU POPUNJAVANJA POZICIJA}

\section{THE EFFECTIVENESS OF RECRUITMENT METHODS IN THE PROCESS OF FILLING UP VACANCIES}

\author{
Ivana Pećanac ${ }^{1}$, Lazar Dražeta ${ }^{1}$, Borivoje Đokić ${ }^{2}$ \\ ${ }^{1}$ Univerzitet Singidunum, Beograd, Republika Srbija \\ ${ }^{2}$ Keiser University, Fort Lauderdale, Florida, USA
}

\begin{abstract}
Apstrakt:
Sektor ljudskih resursa je od izuzetne važnosti u poslovanju jer je posvećen povećanju vrednosti ljudskog kapitala kao osnovnoj konkurentnoj prednosti savremenih organizacija. Jedna od važnih aktivnosti koje sektor za upravljanje ljudskim resursima obavlja je popunjavanje pozicija, kao proces privlačenja, odabira, angažovanja i zadržavanja radne snage čiji kvalitet i broj direktno utiču na poslovanje organizacije. Metode koje se koriste u procesu regrutovanja znatno se razlikuju između različitih organizacija i industrija, s tim da ne postoji jasna korelacija između načina oglašavanja i izvora kojima su zaposleni privučeni da se jave na konkurs u organizaciji. U ovom radu, korišćenjem ankete i razgovora sa zaposlenima, posmatrani su odnosi između metoda regrutovanja i izvora informacija o upražnjenim radnim mestima u nekoliko oblasti poslovanja. Cilj je da se utvrdi efektivnost metoda regrutovanja u privlačenju kvalifikovanih kandidata radi popunjavanja upražnjenih pozicija u organizaciji.
\end{abstract}

Ključne reči:

ljudski resursi, metode regrutovanja, popunjavanje pozicija.

\section{UVOD}

Savremeno poslovanje u turbuletnom poslovnom okruženju globalnog tržišta nalaže da se ljudskim resursima treba baviti strategijski. Ljudski kapital je prepoznat kao glavni pokretač razvoja i održivosti organizacija, ali i jedina vrednost nad kojom organizacija nema pravno vlasništvo (Bhutoria, 2006). Nematerijalne vrednosti (intangible assets) koje nastaju kao rezultat rada zaposlenih danas čine najveći deo tržišne vrednosti S\&P 500 organizacija, iako nemaju fizičku formu i time knjigovodstvenu vrednost (Ocean Tomo, 2010). Pošto je današnja ekonomija znanja zasnovana na ljudskom kapitalu kao osnovnom izvoru bogatstva, inovativne organizacije sa jakim portfoliom proizvoda i usluga stvorenih kao rezultat rada zaposlenih osiguraće sebi održivost poslovanja u uslovima globalne konkurencije.

Proces popunjavanja pozicija, čime se održava stalni priliv kvalitetnog ljudskog kapitala u organizaciji, sastoji se od dva koraka: regrutovanja (privlačenja) kvalifikovanih kandidata i selekcije (odabira) prijavljenih kandidata koji najbolje odgovaraju zahtevima upražnjenog radnog mesta (Đorđević Boljanović et $a l, 2013$ ). Izbor efektivnog načina privlačenja svakoj organizaciji uvećava mogućnosti i, kada govorimo o regrutovanju izvan or-

\section{Abstract:}

The human resources sector is of the utmost importance in doing business, since it is dedicated to increasing the value of human capital, as the key competitive advantage of contemporary organizations. One of the important activities the human resources sector deals with is filling up staff vacancies, as a process of attracting, selecting, engaging and retaining the workforce, whose quality and number directly affect the organization's business results. The methods used in the recruitment process differ significantly between different organizations and industries, and there is no clear correlation between the mode of advertising and resources used to encourage employees to apply for the vacancies. This paper examines the relationship between recruitment methods and sources of information in several business fields by means of questionnaire and interviews with the employees. It aims to determine the efficiency of recruitment methods with the aim of attracting the qualified candidates for filling up vacancies within an organization.

\section{Key words:}

human resources, recruitment methods, staffing.

ganizacije, najvažniju ulogu u tome imaju metode regrutovanja.

Međutim, dva izveštaja, koja su inicirala ovo istraživanje ukazala su na moguć nesklad između korišćenja metoda regrutovanja u organizacijama i izvora informacija koje potencijalni kandidati dobijaju o upražnjenim radnim mestima. Tako npr. informisanje od strane zaposlenih prema Labour Force anketi urađenoj na preko milion ispitanika predstavlja najvažniji izvor informacija potencijalnih kandidata o upražnjenom radnom mestu (Labour Market Trends, 2002), dok se prema CIPD anketi ovaj metod regrutovanja nalazi tek na 6-7. mestu po zastupljenosti, kod preko 800 organizacija u Velikoj Britaniji (CIPD, 2006). S obzirom na cenu koštanja popunjavanja pozicija (CIPD, 2009), od velike je važnosti za poslodavce da utvrde efektivnost metoda koje koriste za privlačenje kvalifikovanih kandidata, $\mathrm{tj}$. da formalnim sredstvima procene ishod regrutovanja.

\section{METODOLOGIJA}

Za istraživanje efikasnosti metoda regrutovanja u organizacijama koje posluju u Republici Srbiji korišćena je tehnika anketiranja putem upitnika za dve grupe ispitanika: zaposlenih u 
odeljenju ljudskih resursa i ostalih zaposlenih u organizaciji. U istraživanju je učestvovalo ukupno šest organizacija iz tri različite oblasti poslovanja i to: informacionih tehnologija, marketinga i poslovnih finansija.

Anketa za zaposlene u odeljenju ljudskih resursa imala je za cilj utvrđivanje zastupljenosti metoda koje njihove organizacije koriste u procesu regrutovanja. Anketa se sastojala od 12 pitanja, zatvorenog tipa (sa ponuđenim odgovorima) i sa mogućnošću da se dodaju komentari u predviđenom slobodnom polju. Anketa za ostale zaposlene u organizacijama imala je 9 zatvorenih pitanja sa ponuđenim metodama regrutovanja, kojima su oni privučeni da konkurišu za upražnjeno radno mesto na poslu koji sada obavljaju. Anketu je iz odeljenja za upravljanje ljudskim resursima popunjavao po jedan zaposleni, dok je anketu namenjenu ostalim zaposlenim u organizacijama popunilo ukupno 47 ljudi.

Kvantitativni metod statističke analize korišćen je u ovoj studiji. Dizajn istraživanja omogućio je dihotomne odgovore ispitanika ("da" i "ne") prilikom upita zaposlenima u organizacijama i njihovim odeljenjima za upravljanje ljudskim resursima. Nakon prikupljanja podataka, primenjena je neparametrijska statistička analiza (Kolmogorov-Smirnov test) metoda regrutovanja, kao odgovora dobijenih od strane ispitanika.

\section{REZULTATI I DISKUSIJA}

Veličina uzorka je uslovila odabir neparametrijske statističke analize rezultata istraživanja. Primenivši KolmogorovSmirnov test utvrdili smo da postoji statistički značajna razlika između metoda privlačenja kandidata koje organizacije koriste u procesu regrutovanja i načina na koji su anketirani zaposleni saznali za upražnjeno radno mesto na poslu koji sada obavljaju (Tabela 1). Osenčena polja označavaju podudarnost između metoda regrutovanja za dve grupe ispitanika: zaposlenih u organizaciji i odeljenju ljudskih resursa.

\begin{tabular}{|c|l|l|}
\hline Rang & \multicolumn{1}{|c|}{ Zaposleni } & \multicolumn{1}{|c|}{$\begin{array}{c}\text { Odeljenje ljudskih } \\
\text { resursa }\end{array}$} \\
\hline 1 & Preporuke zaposlenih & Obrazovne institucije \\
\hline 2 & Poslovni Internet sajtovi & Poslovni Internet sajtovi \\
\hline 3 & Agencije za zapošljavanje & Javni mediji \\
\hline 4 & Sajt organizacije & Preporuke zaposlenih \\
\hline 5 & Oglasi u novinama & Sajt organizacije \\
\hline 6 & Obrazovne institucije & Drugo \\
\hline 7 & Javni mediji & Agencije za zapošljavanje \\
\hline 8 & Posteri i bilbordi & Oglasi u novinama \\
\hline 9 & Drugo & Posteri i bilbordi \\
\hline 10 & Specijalizovani časopisi & Specijalizovani časopisi \\
\hline
\end{tabular}

Tabela 1. Poređenje metoda regrutovanja iz sve tri oblasti poslovanja

Zbirna statistička analiza pokazuje nesklad između načina privlačenja koje koriste organizacije i saznanja kandidata za upražnjena radna mesta, ali bez reference ka svakoj od tri različite oblasti poslovanja. Zbog malog uzorka, rezultati nisu potvrđeni na nivou svake industrije posebno (dve organizacije po industriji), ali su prikazani kroz poređenje metoda regrutovanja (Tabele 2-4) I ovde, osenčena polja označavaju podudarnost između metoda regrutovanja za obe grupe ispitanika.

\begin{tabular}{|c|l|l|}
\hline Rang & \multicolumn{1}{|c|}{ Zaposleni } & \multicolumn{1}{|c|}{$\begin{array}{c}\text { Odeljenje ljudskih } \\
\text { resursa }\end{array}$} \\
\hline 1 & Preporuke zaposlenih & Preporuke zaposlenih \\
\hline 2 & Obrazovne institucije & Obrazovne institucije \\
\hline 3 & Sajt organizacije & Poslovni Internet sajtovi \\
\hline 4 & Poslovni Internet sajtovi & Javni mediji \\
\hline 5 & Javni mediji & Drugo \\
\hline 6 & Oglasi u novinama & Sajt organizacije \\
\hline 7 & Agencije za zapošljavanje & Posteri i bilbordi \\
\hline 8 & Posteri i bilbordi & Agencije za zapošljavanje \\
\hline 9 & Specijalizovani časopisi & Specijalizovani časopisi \\
\hline 10 & Drugo & Oglasi u novinama \\
\hline
\end{tabular}

Tabela 2. Poređenje metoda regrutovanja iz oblasti informacionih tehnologija

\begin{tabular}{|c|l|l|}
\hline Rang & \multicolumn{1}{|c|}{ Zaposleni } & \multicolumn{1}{|c|}{$\begin{array}{c}\text { Odeljenje ljudskih } \\
\text { resursa }\end{array}$} \\
\hline 1 & Poslovni Internet sajtovi & Poslovni Internet sajtovi \\
\hline 2 & Preporuke zaposlenih & Obrazovne institucije \\
\hline 3 & Agencije za zapošljavanje & Javni mediji \\
\hline 4 & Oglasi u novinama & Oglasi u novinama \\
\hline 5 & Sajt organizacije & Agencije za zapošljavanje \\
\hline 6 & Specijalizovani časopisi & Sajt organizacije \\
\hline 7 & Obrazovne institucije & Preporuke zaposlenih \\
\hline 8 & Posteri i bilbordi & Drugo \\
\hline 9 & Javni mediji & Specijalizovani časopisi \\
\hline 10 & Drugo & Posteri i bilbordi \\
\hline
\end{tabular}

Tabela 3. Poređenje metoda regrutovanja iz oblasti finansija

\begin{tabular}{|c|l|l|}
\hline Rang & \multicolumn{1}{|c|}{ Zaposleni } & \multicolumn{1}{|c|}{$\begin{array}{c}\text { Odeljenje ljudskih } \\
\text { resursa }\end{array}$} \\
\hline 1 & Preporuke zaposlenih & Poslovni Internet sajtovi \\
\hline 2 & Agencije za zapošljavanje & Obrazovne institucije \\
\hline 3 & Poslovni Internet sajtovi & Preporuke zaposlenih \\
\hline 4 & Oglasi u novinama & Agencije za zapošljavanje \\
\hline 5 & Sajt organizacije & Oglasi u novinama \\
\hline 6 & Specijalizovani časopisi & Sajt organizacije \\
\hline 7 & Obrazovne institucije & Javni mediji \\
\hline 8 & Posteri i bilbordi & Specijalizovani časopisi \\
\hline 9 & Javni mediji & Posteri i bilbordi \\
\hline 10 & Drugo & Drugo \\
\hline
\end{tabular}

Tabela 4. Poređenje metoda regrutovanja iz oblasti marketinga

Evidentno je da ispitane organizacije iz oblasti informacionih tehnologija imaju najveći stepen podudarnost između najučestalijih metoda regrutovanja, tj. preporuka zaposlenih i obrazovnih institucija, za obe grupe ispitanika. Organizacije iz oblasti finansija imaju delimično poklapanje, kod prve i četvr- 
te rangirane metode dok oblast marketinga pokazuje najveću nepodudarnost $\mathrm{u}$ rangiranju metoda regrutovanja kojima se organizacije oglašavaju i načina na koji su zaposleni u tim organizacijama saznali za upražnjeno radno mesto na poslu koji sada obavljaju.

Obzirom na prirodu posla i zahteve kvalifikacija zaposlenih, može se reći da postoji visok stepen efikasnosti u metodama regrutovanja organizacija iz oblasti informacionih tehnologija. Preporuke zaposlenih i saradnja sa obrazovnim institucijama predstavljaju glavni izvor privlačenja kvalifikovanih kandidata, dok se nekoliko drugih metoda malo razlikuje po učestalosti pojavljivanja kod obe grupe ispitanika (npr. poslovni veb-sajtovi, javni mediji). Obe najučestalije metode regrutovanja se po prirodi fokusiraju na privlačenje kroz lični kontakt sa kandidatima i najčešće zahtevaju dokazana stručna znanja i veštine, kao i poznate osobine kandidata (Dessler, 2007).

U oblasti finansija postoji takođe podudarnost dve metode, ali sa većom razlikom $u$ rangiranju kod obe grupe ispitanika (poslovni Internet sajtovi i oglasi u novinama). Zabrinjavajuća je činjenica da se preporuke nalaze da drugom mestu po rangiranju zaposlenih, ali zato na sedmom mestu po zastupljenosti metoda kojima odeljenje ljudskih resursa oglašava upražnjena radna mesta. U oblasti marketinga najmanja je podudarnost između metoda regrutovanja za obe grupe ispitanika ali se npr. preporuke zaposlenih, kao dominantni način kojim su zaposleni bili regrutovani nalaze na trećem mestu po zastupljenosti metoda oglašavanja u ovim organizacijama.

Zanimljivo je da se u svim ispitanim organizacijama iz različitih oblasti poslovanja preporuke zaposlenih nalaze na vrhu liste metoda regrutovanja kojima su zaposleni saznali za upražnjeno radno mesto na poslu koji sada obavljaju. Globalna istaživanja takođe pokazuju da je to jedan od najefektivnijih izvora kandidata (Labour Market Trends, 2002; Dessler, 2007). Ovo je od posebne važnosti za poslodavce i kandidate u Republici Srbiji, jer statistike pokazuju da je tokom 2014. godine za svako upražnjeno radno mesto u proseku konkurisalo 154 kandidata (Infostud, 2014). Uzevši u obzir prosečnu cenu koštanja popunjavanja pozicije, koja u nekim razvijenim zemljama iznosi preko $5000 €(C I P D, 2009)$, ne može se potceniti značaj regrutovanja za savremene organizacije.

\section{ZAKLJUČAK}

Regrutovanje, kao prvi korak u procesu popunjavanja pozicija kojim se vrši privlačenje kvalifikovanih kandidata direktno utiče na stalni priliv kvalitetnog ljudskog kapitala u organizaci- ji. Pritom, regrutovanje zahteva poznavanje načina oglašavanja na tržištu rada ali i prilagođavanje ciljnoj grupi, koje ne zavisi samo od organizacionih potreba već i od opisa radnog mesta za svaku poziciju. Takav pristup mora biti osnovno merilo uspeha, ukoliko organizacije žele da budu konkurentne i da se prilagođavaju poslovnim zahtevima kako unutar organizacije, tako i u spoljašnjem okruženju.

U ovom radu, posmatrani su odnosi između metoda regrutovanja kojima organizacije privlače odgovarajuće kandidate i načina na koji su zaposleni u tim organizacijama saznali za upražnjeno radno mesto na poslu koji sada obavljaju. Kao metod je korišćena anketa i razgovor sa dve grupe ispitanika: zaposlenih u odeljenju ljudskih resursa i ostalih zaposlenih u organizaciji. U istraživanju je učestvovalo ukupno šest organizacija iz oblasti informacionih tehnologija, marketinga i poslovnih finansija. Istraživanjem smo hteli da ukažemo na različitu efektivnost metoda regrutovanja, kako bi organizacije spram okruženja u kome posluju optimizovale ne samo načine privlačenja najkvalitetnijih kandidata već i troškove popunjavanja pozicija.

\section{LITERATURA}

Bhutoria N. (2006). Valuation of Human Capital. Preuzeto sa www.hrfolks.com/articles/intellectual\%20capital/valuation\%20of\%20human\%20capital.pdf

CIPD. (2006). Recruitment, Retention and Turnover: Annual Survey Report. Lindon: CIPD, Preuzeto iz: Thorrington, D., Hall, L., Taylor, S. (2008). Human resource management. Harlow: Pearson Education Ltd.

CIPD. (2009). Annual Survey Report 2009. Recruitment, Retention and Turnover. Preuzeto sa http://www.cipd.co.uk/binaries/ recruitment_retention_turnover_annual_survey_2009.pdf

Dessler, G. (2007). Osnovi menadžmenta ljudskih resursa. Beograd: Data Status.

Đorđević Boljanović, J., Dražeta, L., Babić, L., \& Dobrijević, G. (2013) Razvoj karijere i poslovnih veština. Beograd: Univerzitet Singidunum.

Infostud (2014). Najtraženija zanimanja u 2014. godini na sajtu Poslovi infostud. Preuzeto sa https://poslovi.infostud.com/ trazena-zanimanja/2014

Labour Market Trends (2002). Labour Market Spotlight. Preuzeto iz: Thorrington, D., Hall, L., Taylor, S. (2008). Human resource management. Harlow: Pearson Education Ltd.

Ocean Tomo. (2010). Intangible Asset Market Value Study. Preuzeto sa http://www.oceantomo.com/ 